\title{
CULTIVATION OF CUSTARD-APPLE IRRIGATED WITH SALINE WATER UNDER COMBINATIONS OF NITROGEN, PHOSPHORUS AND POTASSIUM ${ }^{1}$
}

\author{
ANDRÉ ALISSON RODRIGUES DA SILVA ${ }^{2 *}$, LUANA LUCAS DE SÁ ALMEIDA VELOSO², GEOVANI SOARES \\ DE LIMA ${ }^{2}$, HANS RAJ GHEYI ${ }^{2}$, FRANCISCO VANIES DA SILVA SÁ ${ }^{3}$, CARLOS ALBERTO VIEIRA DE \\ $\mathrm{AZEVEDO}^{2}$
}

\begin{abstract}
The objective of this study was to evaluate the effect of combinations of nitrogen, phosphorous and potassium doses on the production components of custard-apple irrigated with saline waters. The experiment was conducted in a greenhouse, using a Neossolo Regolítico (Entisol) of clay loam texture in Campina Grande-PB, Brazil. The treatments were distributed in a randomized block design, in a $2 \times 8$ factorial scheme, with three replicates, corresponding to two levels of electrical conductivity of water $-\mathrm{ECw}(0.8$ and $\left.3.0 \mathrm{dS} \mathrm{m}^{-1}\right)$ and eight combinations of fertilization with nitrogen, phosphorus and potassium (100-100-100; 100 $-100-125 ; 100-125-100 ; 100-125-125 ; 125-100-100 ; 125-100-125 ; 125-125-100$ and $125-125-125 \%$ of the recommendation, for the third year of cultivation). The combination of $100-100-100 \%$ corresponded to 100,60 and $60 \mathrm{~g}$ of $\mathrm{N}, \mathrm{P}_{2} \mathrm{O}_{5}, \mathrm{~K}_{2} \mathrm{O}$ per plant per year, respectively. High concentrations of salts in the irrigation water reduced the number of fruits, fresh fruit mass, total number of seeds and mass of seeds of custard-apple. Plants achieved the best development when grown under 125-100-100, 125-125-125 and 100-100-100\% combinations of N-P-K recommendation. Irrigation with ECw of $3.0 \mathrm{dS} \mathrm{m}^{-1}$ associated with the $100-125-125 \%$ combination of fertilization increased the average mass and height of the custard-apple fruits.
\end{abstract}

Keywords: Annona squamosa L.. Salt stress. Mineral nutrition.

\section{CULTIVO DA PINHA IRRIGADA COM ÁGUA SALINA SOB COMBINAÇÕES DE NITROGÊNIO, FÓSFORO E POTÁSSIO}

RESUMO - Objetivou-se com este estudo avaliar o efeito das combinações de doses de nitrogênio, fosforo e potássio nos componentes de produção da pinheira irrigadas com águas salinas. $\mathrm{O}$ experimento foi desenvolvido em casa de vegetação, utilizando-se de um Neossolo Regolítico (Entisol) de textura francoargilosa em Campina Grande-PB. Os tratamentos foram distribuídos em delineamento experimental em blocos ao acaso, em esquema fatorial $2 \times 8$, com três repetições, sendo dois níveis de condutividade elétrica da água CEa $\left(0,8\right.$ e 3,0 dS m$\left.~^{-1}\right)$ e oito combinações de adubação com nitrogênio, fósforo e potássio (100-100-100; 100$100-125 ; \quad 100-125-100 ; \quad 100-125-125 ; \quad 125-100-100 ; \quad 125-100-125 ; \quad 125-125-100$ e $125-125-125 \%$ da recomendação, referente ao terceiro ano de cultivo). A combinação de 100-100-100\% correspondeu a 100, 60 e $60 \mathrm{~g}$ de $\mathrm{N}, \mathrm{P}_{2} \mathrm{O}_{5}, \mathrm{~K}_{2} \mathrm{O}$ por planta anual, respectivamente. As altas concentrações de sais na água de irrigação diminuiu o número de frutos, a massa fresca de frutos, número total e a massa de sementes da pinheira. As plantas de pinha alcançaram o melhor desenvolvimento quando cultivadas nas combinações 125-100-100; 125-

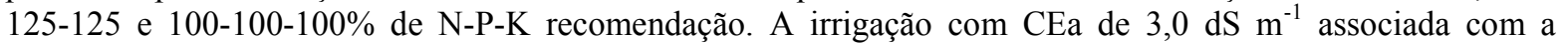
combinação de adubação 100-125-125\% aumentou a massa média e altura dos frutos de pinheira.

Palavras-chave: Anonna squamosa L.. Estresse salino. Nutrição mineral.

\footnotetext{
*Corresponding author

${ }^{1}$ Received for publication in 09/18/2020; accepted in 07/26/2021.

${ }^{2}$ Academic Unit of Agricultural Engineering, Center of Technology and Natural Resources, Universidade Federal de Campina Grande, Campina Grande, PB, Brazil; andrealisson cgpb@hotmail.com- ORCID: 0000-0001-9453-1192, luana lucas 15@hotmail.com - ORCID: 0000-0003-0537-7985, geovani.soares@pq.cnpq.br - ORCID: 0000-0001-9960-1858, hans@pq.cnpq.br - ORCID: 0000-0002-1066-0315, cvieiradeazevedo@gmail.com - ORCID: 0000-0001-7336-1243.

${ }^{3}$ Department of Agricultural Sciences, Universidade Federal Rural do Semi-Árido, Mossoró, RN, Brazil; vanies_agronomia@hotmail.com - ORCID: 0000-0001-6585-8161.
} 


\section{INTRODUCTION}

Custard-apple (Annona squamosa L.) is a fruit crop belonging to the Annonaceae family, which has stood out due to its economic importance for the Northeast region, especially in the states of Bahia, Pernambuco and Ceará, which have the highest levels of productions of this fruit in the country (ANDRADE et al., 2018).

Despite the good adaptation of custard-apple to the Brazilian Northeast, in this region its productive potential is limited by the water quality, especially in its semi-arid region, due to the spatial and temporal irregularity of rainfall, which increases the concentration of salts in water, especially sodium contents, which have negative effects on plants, resulting in lower growth and production of crops (SILVA et al., 2018; DIAS et al., 2019).

In general, plants subjected to salinity are subject to reduction in the osmotic potential of the soil solution and possible occurrence of nutritional imbalance and metabolic disorders, both caused by the high concentration of toxic ions in the protoplasm, especially $\mathrm{Na}^{+}$and $\mathrm{Cl}^{-}$, leading to disturbances in water relations and, consequently, changes in the absorption and use of nutrients, so it is important to identify materials with potential tolerance (FLOWERS; MUNNS; COLMER, 2014; OUHADDACH et al., 2018).

Nitrogen, phosphorus and potassium are the nutrients most exported by custard-apple and have been reported to have a pronounced effect on fruit quality (SÃO JOSÉ et al., 2014), which may enable fertilization management and irrigation with high salt content in semi-arid areas of Northeastern Brazil. Therefore, studies have been carried out using saline water in custard-apple cultivation in the Northeast region, such as that of Fernandes et al. (2021), who observed reductions of growth when plants were irrigated with water of $4.0 \mathrm{dS} \mathrm{m} \mathrm{m}^{-1}$. Ferreira et al. (2021) found that irrigation with water of $3.0 \mathrm{dS} \mathrm{m}^{-1}$ negatively affected photosynthetic pigments and increased damage to the cell membrane. However, there are few studies contemplating the use of saline waters up to the reproductive stage of the crop.

One of the alternatives for coping with this problem is the adequate management of fertilization, which can enable the use of saline water as an alternative to the limited availability of good quality water, because ionic toxicity, evidenced by changes in the $\mathrm{K}^{+} / \mathrm{Na}^{+}, \mathrm{Ca}^{2+} / \mathrm{Na}^{+}$and $\mathrm{NO}_{3}{ }^{-} / \mathrm{Cl}^{-}$ratios of the tissues can be reduced by increasing the values of these ratios in leaves, reducing the nutritional imbalance in plants (ALVARENGA et al., 2019). Thus, the objective was to evaluate the effect of nitrogen, phosphorus and potassium combinations on the production components of custard-apple irrigated with saline waters.

\section{MATERIAL AND METHODS}

The experiment was carried out during the period from December 2018 to December 2019, in a protected environment of the Center for Technology and Natural Resources - CTRN of the Federal University of Campina Grande - UFCG, located in the municipality of Campina Grande, PB, Brazil, at the geographic coordinates $7^{\circ} 15^{\prime} 18^{\prime \prime}$ South latitude, $35^{\circ} 52^{\prime} 28^{\prime \prime}$ West longitude and average altitude of $550 \mathrm{~m}$.

The treatments consisted of two levels of electrical conductivity of the water - $\mathrm{ECw}(0.8$ and $3.0 \mathrm{dS} \mathrm{m}^{-1}$ ) and eight combinations of fertilization with nitrogen, phosphorus and potassium - N-P-K $\left(C_{1}=100-100-100 ; C_{2}=100-100-125 ; C_{3}=100-125\right.$ $-100 ; \mathrm{C}_{4}=100-125-125 ; \mathrm{C}_{5}=125-100-100 ; \mathrm{C}_{6}=125$ $-100-125 ; C_{7}=125-125-100$ and $C_{8}=125-125-$ $125 \%$ of N-P-K recommendation), in a $2 \times 8$ factorial arrangement, distributed in randomized blocks, with three replicates, totaling 48 experimental units. The recommendation of fertilization used in the study was proposed by Silva and Silva (1997) for Annonaceae species. The combination of 100-100-100\% corresponded to 100 , 60 and $60 \mathrm{~g}$ of $\mathrm{N}, \mathrm{P}_{2} \mathrm{O}_{5}, \mathrm{~K}_{2} \mathrm{O}$ per plant per year, respectively, referring to the third year of cultivation.

Crioulo custard-apple seedlings, produced from seeds acquired from a certified commercial nursery in the state of Pernambuco, were used in the experiment. At the end of the second year of cultivation, the plants were subjected to a period of 15 days of water stress and, subsequently, a cleaning pruning was performed. After pruning, the third year of cultivation began. The treatments began to be applied at 20 days after pruning (DAP).

The study was conducted using plastic pots adapted as drainage lysimeters, with capacity of 250 $\mathrm{L}$, filled with a $1.0-\mathrm{kg}$ layer of crushed stone $\left(\mathrm{n}^{\circ} 0\right)$ followed by $235 \mathrm{~kg}$ of soil classified as Neossolo Regolitico (Entisol) of clay loam texture collected at a depth of $0-30 \mathrm{~cm}$, from the municipality of Lagoa Seca-PB. After a sample was taken, it was pounded to break up clods and characterized according for the physico-chemical attributes following the methodology of Teixeira et al. (2017): $\mathrm{Ca}^{2+}=$ $3.49 \mathrm{cmol}_{\mathrm{c}} \mathrm{kg}^{-1} ; \mathrm{Mg}^{2+}=2.99 \mathrm{cmol}_{\mathrm{c}} \mathrm{kg}^{-1} ; \mathrm{Na}^{+}=$ $0.17 \mathrm{cmol}_{\mathrm{c}} \mathrm{kg}^{-1} ; \mathrm{K}^{+}=0.21 \mathrm{cmol}_{\mathrm{c}} \mathrm{kg}^{-1} ; \mathrm{H}^{+}+\mathrm{Al}^{3+}=$ $5.81 \mathrm{cmol}_{\mathrm{c}} \mathrm{kg}^{-1}$; organic matter $=1.83 \mathrm{dag} \mathrm{kg}{ }^{-1} ; \mathrm{P}=$ $18.20 \mathrm{mg} \mathrm{kg}^{-1} ; \mathrm{pH}$ in water $(1: 2.5)=5.63$; electrical conductivity of saturation extract $=0.61 \mathrm{dS} \mathrm{m}^{-1}$; exchangeable sodium percentage $=2.48 \%$; sand $=$ $573 \mathrm{~g} \mathrm{~kg}^{-1}$; silt $=101 \mathrm{~g} \mathrm{~kg}^{-1}$; clay $=326 \mathrm{~g} \mathrm{~kg}^{-1}$; moisture at $33.42 \mathrm{kPa}=12.68 \mathrm{dag} \mathrm{kg}^{-1}$; moisture at $1519.5 \mathrm{kPa}=4.98 \mathrm{dag} \mathrm{kg}^{-1}$; total porosity $=$ $0.57 \mathrm{~m}^{3} \mathrm{~m}^{-3}$; bulk density $=1.13 \mathrm{~kg} \mathrm{dm}^{-3}$; particle density $=2.65 \mathrm{~kg} \mathrm{dm}^{-3}$.

The saline waters were prepared by the 
addition of $\mathrm{NaCl}, \mathrm{CaCl}_{2} \cdot 2 \mathrm{H}_{2} \mathrm{O}$ and $\mathrm{MgSO}_{4} \cdot 7 \mathrm{H}_{2} \mathrm{O}$ salts to water from the public supply system of the municipality of Campina Grande, maintaining an equivalent proportion of $7: 2: 1$, which represents the average composition of the waters of the semi-arid Northeast region (MEDEIROS, 1992). The sources of nitrogen, phosphorus, and potassium were urea $(45 \% \mathrm{~N})$, monoammonium phosphate $\left(61 \% \mathrm{P}_{2} \mathrm{O}_{5}\right.$, $11 \% \quad \mathrm{~N})$ and potassium chloride $\left(60 \% \mathrm{~K} \mathrm{~K}_{2} \mathrm{O}\right)$, respectively. Fertilization was performed by fertigation twice a month, carried out in the first and fourth week of each month. Micronutrient applications were performed weekly by spraying the leaves on the abaxial and adaxial sides using $2.5 \mathrm{~g} \mathrm{~L}^{-1}$ of the foliar fertilizer Quimifol Nutri ${ }^{\circledR}$, containing $25 \%$ potassium $\left(\mathrm{K}_{2} \mathrm{O}\right), 2.5 \%$ magnesium, $6.0 \%$ sulfur, $2.0 \%$ boron, $0.5 \%$ copper, $0.3 \%$ molybdenum and $5.0 \%$ zinc.

The irrigation events were carried out with an interval of 3 days, applying in each lysimeter a volume of water to maintain soil moisture close to field capacity, and the volume to be applied was determined every two weeks according to the water requirement of the plants by means of water balance, according to Equation 1:

$$
\mathrm{VI}=\frac{(\mathrm{Va}-\mathrm{Vd})}{(1-\mathrm{LF})}
$$

Where:

VI - volume of water to be applied in the irrigation event $(\mathrm{mL})$;

$\mathrm{Va}$ - volume applied in the previous irrigation event $(\mathrm{mL})$;

$\mathrm{Vd}$ - drained volume $(\mathrm{mL})$;

LF - leaching fraction of 0.10 , applied every 30 days to avoid excessive accumulation of salts in the root zone (AYERS;WESTCOT, 1999).

Throughout the experiment, manual weeding, surface scarification of the soil to remove compacted layer and corrective pruning were performed. Pollination was carried out artificially using a brush, by collecting pollen and deposited on the stigma. The production components were evaluated based on the total number of fruits (TNF), fresh fruit mass (FFM), average fruit mass (AFM), average number of seeds per fruit (ANSF), total mass of seeds (TMS), mass of one hundred seeds $\left(\mathrm{M}_{100 \mathrm{~S}}\right)$, fruit diameter (FD) and fruit height (FH).

Harvest began at 300 days after pruning (DAP) and extended to 350 DAP; physiologically ripe fruits were harvested twice a week. Physiological maturity is recognized through the greater separation between the stylar ends and the loss of consistency of these structures (SÃO JOSÉ et al., 2000). At each harvest, fruits were weighed on a scale with accuracy of $0.01 \mathrm{~g}$. The number of seeds was obtained by counting all seeds produced per plant and weighing them. The mass of seeds was then corrected to $10 \%$ moisture according to the methodology of Brasil (2009). A digital caliper was used to determine fruit diameter (FD) and height (FH).

The collected data were subjected to analysis of variance by the $\mathrm{F}$ test and, when significant, Tukey test was performed at 0.05 probability level for the salinity levels, while the NPK fertilization combinations were compared using the Scott-Knott test, further follow up analysis of the interaction was carried out at 0.05 probability level, whenever it was significant using the statistical program Sisvar (FERREIRA, 2019).

\section{RESULTS AND DISCUSSION}

The interaction between water salinity levels and fertilization combinations (Table 1) significantly influenced the average fruit mass (AFM) and fruit height (FH). Individually, salinity levels and fertilization combinations significantly affected all variables analyzed, except for FD. Similar results were observed by Ferreira (2020), who evaluated custard-apple irrigated with waters of different salinities under different doses of fertilization with nitrogen, phosphorus and potassium, and noted the effect of the different salinities of irrigation water on the production variables.

Table 1. Summary of the analysis of variance for total number of fruits (TNF), fresh fruit mass (FFM), average fruit mass (AFM), average number of seeds per fruit (ANSF), total mass of seeds (TMS), mass of one hundred seeds ( $\mathrm{M}_{100 \mathrm{~S}}$ ), fruit diameter (FD) and fruit height (FH) of custard-apple irrigated with saline waters and subjected to different combinations of fertilization with NPK, at 350 days after pruning (DAP).

\begin{tabular}{|c|c|c|c|c|c|c|c|c|c|}
\hline \multirow{2}{*}{ Source of variation } & \multirow{2}{*}{ DF } & \multicolumn{8}{|c|}{ Mean squares } \\
\hline & & TNF & FFM & AFM & ANSF & TMS & $\mathrm{M}_{100 \mathrm{~S}}$ & FD & $\mathrm{FH}$ \\
\hline Salinity levels - SN & 1 & $8.33^{* *}$ & $100561.27^{* *}$ & $1479.07^{* *}$ & $99.76^{*}$ & $223.64^{* *}$ & $42.11^{* *}$ & $146.02^{\mathrm{ns}}$ & $14.70^{* *}$ \\
\hline Combinations of fertilization - CF & 7 & $2.62^{* *}$ & $56480.51^{* *}$ & $2068.83^{* *}$ & $386.1^{* *}$ & $376.32^{* *}$ & $108.53^{* *}$ & $110.89^{\mathrm{ns}}$ & $54.27^{* *}$ \\
\hline Interaction $-(\mathrm{SN} \times \mathrm{CF})$ & 7 & $3.33^{\mathrm{ns}}$ & $38786.09^{\mathrm{ns}}$ & $4212.39^{* *}$ & $78.51^{\mathrm{ns}}$ & $270.14^{\mathrm{ns}}$ & $54.32^{\mathrm{ns}}$ & $176.59^{\mathrm{ns}}$ & $84.68^{* *}$ \\
\hline Blocks & 2 & $0.39^{\mathrm{ns}}$ & $487.35^{\mathrm{ns}}$ & $154.25^{\mathrm{ns}}$ & $15.11^{\mathrm{ns}}$ & $79.27^{\mathrm{ns}}$ & $0.34^{\mathrm{ns}}$ & $71.53^{\mathrm{ns}}$ & $0.86^{\mathrm{ns}}$ \\
\hline Residue & 30 & 0.46 & 11266.59 & 128.10 & 16.51 & 29.69 & 2.03 & 94.12 & 1.65 \\
\hline $\mathrm{CV}(\%)$ & - & 13.16 & 11.82 & 6.33 & 12.75 & 14.57 & 6.62 & 15.13 & 1.68 \\
\hline
\end{tabular}

ns, ${ }^{*}{ }^{* *}$ respectively not significant and significant at $\mathrm{p}<0.05$ and $\mathrm{p}<0.01$.

Rev. Caatinga, Mossoró, v. 35, n. 1, p. 181 - 190, jan. - mar., 2022 
For the total number of fruits (Figure 1A), it was found that plants subjected to water salinity of $0.8 \mathrm{dS} \mathrm{m}^{-1}$ had higher TNF compared to those irrigated with water of $3.0 \mathrm{dS} \mathrm{m}^{-1}$ (Figure 1A). ECw of $3.0 \mathrm{dS} \mathrm{m}^{-1}$ caused a decrease of $16.07 \%$ (0.9 fruits per plant) in comparison to plants subjected to salinity of $0.8 \mathrm{dS} \mathrm{m}^{-1}$. Similar results were obtained by Ferreira et al. (2021) in a study conducted with custard-apple (Annona squamosa L.) under salt stress $\left(0.8\right.$ to $\left.3.0 \mathrm{dS} \mathrm{m}^{-1}\right)$, where a reduction of $20.79 \%$ (1.42 fruits per plant) was observed in plants

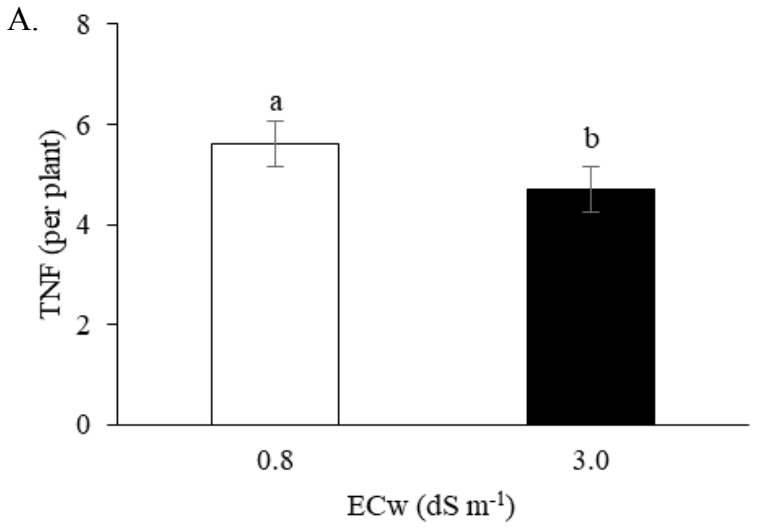

irrigated with the highest salinity level $\left(3.0 \mathrm{dS} \mathrm{m}^{-1}\right)$.

The reduction in the number of fruits may be related to the accumulation of salts in the soil, which leads to a decrease in osmotic potential and greater energy expenditure to absorb water and nutrients, directly interfering in physiological and biochemical processes of the plant, diversion of energy for accumulation of compatible solutes and inhibition of cell division and elongation, which causes a reduction in the growth and production of crops (LIMA et al., 2019).

$\mathrm{C}_{1}=100-100-100 ; \mathrm{C}_{2}=100-100-125 ; \mathrm{C}_{3}=100-125-100 ; \mathrm{C}_{4}=100-125-125 ; \mathrm{C}_{5}=125-100-100 ; \mathrm{C}_{6}=125-100-125 ; \mathrm{C}_{7}=125$ $-125-100$ and $C_{8}=125-125-125 \%$ of the recommended dose of N-P-K; Means followed by the same letter do not indicate significant differences for irrigation water salinity (A) and different combinations of fertilization with N-P-K (B), respectively, by Tukey and Scott-Knott test at 0.05 probability level.

Figure 1. Total number of fruits - TNF of custard-apple as a function of irrigation water salinity - ECw (A) and combinations of fertilization with N-P-K (B), at harvest.

There was no significant difference in the total number of fruits per plant under the combinations of fertilization $\mathrm{C}_{1}, \mathrm{C}_{2}, \mathrm{C}_{4}, \mathrm{C}_{5}$ and $\mathrm{C}_{7}$ (Figure 1B), with average values of $4.67,4.83,5.17$, 4.5 and 4.67 fruits per plant, respectively. It is also worth pointing out that plants fertilized with the combinations of fertilization $\mathrm{C}_{3}$ and $\mathrm{C}_{8}$ had a reduction of $15.38 \%$ (1.0 fruit per plant) compared to those fertilized with the combination $\mathrm{C}_{6}$, which corresponds to fertilization with $125-100-125 \%$ of N-P-K. This result may be related to the supply of the higher proportion of nitrogen and potassium existing in the combination of fertilization $\mathrm{C}_{6}$, since custard-apple is a very demanding fruit crop in terms of nutrients, mainly nitrogen and potassium (CAVALCANTE et al., 2012). In addition, the physiological role of potassium in osmoregulation, being directly involved in the regulation of the cellular osmotic potential, favors homeostasis and consequently the crop yield (CLAEYS et al., 2014).

It can be inferred that there was variation in the fresh fruit mass (FFM) of custard-apple due to irrigation water salinity (Figure 2A). Irrigation using water with $\mathrm{ECW}$ of $0.8 \mathrm{dS} \mathrm{m}^{-1}$ promoted maximum

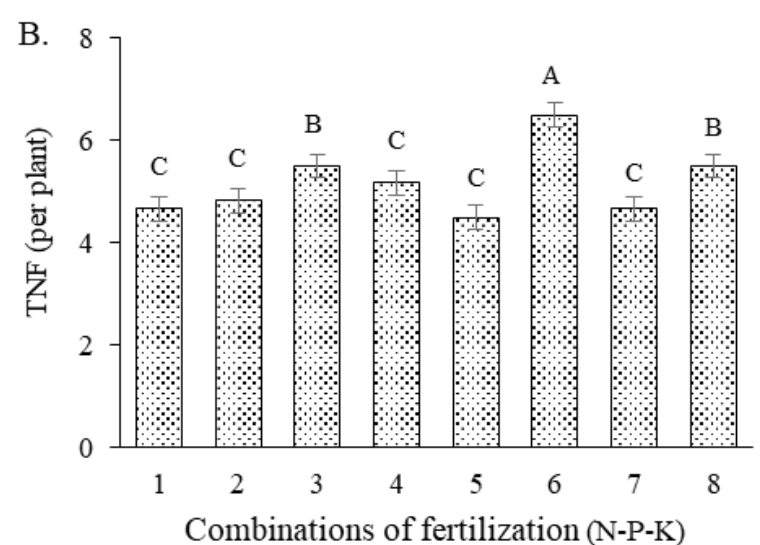

value of FFM (943.9 g per plant) compared to plants subjected to irrigation using water with higher salinity level $\left(3.0 \mathrm{dS} \mathrm{m} \mathrm{m}^{-1}\right)$, that is, there was a decrease of $91.5 \mathrm{~g}$ per plant $(9.69 \%)$ compared to plants that were under irrigation with $0.8 \mathrm{dS} \mathrm{m}^{-1}$. This result corroborates those obtained by Sá et al. (2021) in a study conducted with custard-apple (Anonna squamosa L.) under salt stress ( 0.8 to $3.0 \mathrm{dS} \mathrm{m}^{-1}$ ), where they found a reduction of $20.3 \%$ (217.48 g per plant) in plants irrigated with higher salinity level $\left(3.0 \mathrm{dS} \mathrm{m}^{-1}\right)$.

Regarding the salts applied via irrigation water, part accumulates in the soil while another part is absorbed by the plants and the rest is adsorbed in the soil colloids with the potential to increase the concentration, especially after successive applications, reaching the point of reducing the availability of water to the plants, due to the effect of osmotic nature and consequently, inducing stomatal closure, limiting transpiration, which reduces the rate of photosynthesis, causing a decrease in crop production (DIAS et al., 2018; VELOSO et al., 2019). 




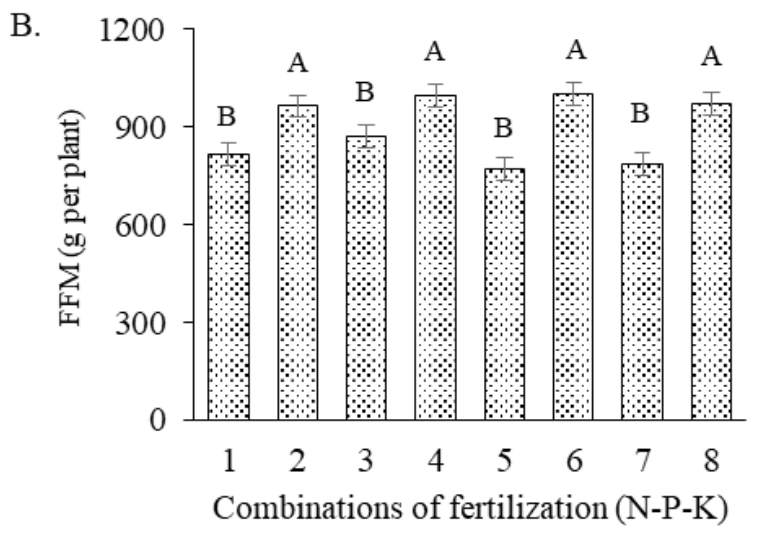

$\mathrm{C}_{1}=100-100-100 ; \mathrm{C}_{2}=100-100-125 ; \mathrm{C}_{3}=100-125-100 ; \mathrm{C}_{4}=100-125-125 ; \mathrm{C}_{5}=125-100-100 ; \mathrm{C}_{6}=125-100-125 ; \mathrm{C}_{7}=$ 125-125-100 and $\mathrm{C}_{8}=125-125-125 \%$ of the recommended dose of N-P-K; Means followed by the same letter do not indicate significant differences for irrigation water salinity (A) and different combinations of fertilization with N-P-K (B), respectively, by Tukey and Scott-Knott test at 0.05 probability.

Figure 2. Fresh fruit mass - FFM of custard-apple as a function of irrigation water salinity - ECw (A) and combinations of fertilization with N-P-K (B), at harvest.

Fresh fruit mass was also significantly influenced by the combinations of N-P-K fertilization (Figure 2B), and the combinations $\mathrm{C}_{2}$, $\mathrm{C}_{4}, \mathrm{C}_{6}$ and $\mathrm{C}_{8}$ did not differ from each other, leading to mean values of $964.45,997.76,1001.39$ and $972.82 \mathrm{~g}$ per plant, respectively, while the lowest values were verified in the combinations $\mathrm{C}_{1}, \mathrm{C}_{3}, \mathrm{C}_{5}$ and $\mathrm{C}_{7}$. Thus, it is clear that nitrogen fertilization in combination with potassium promotes satisfactory results with regard to plant tolerance to salt stress because potassium is recognized as vital for various biological processes in plant cells, such as enzymatic activation, respiration, photosynthesis and improvement in water balance (PRAZERES et al., 2015).

According to Souza et al. (2019), nitrogen has vital functions in plant metabolism, being a constituent of proteins, enzymes, coenzymes, nucleic acids, phytochromes and chlorophyll, besides affecting the rates of leaf initiation and expansion, while potassium controls stomatal movements and is an important metabolic activator essential for protein formation. In addition, the supply of $\mathrm{K}$ and $\mathrm{P}$ reduces the absorption of $\mathrm{Na}^{+}$and $\mathrm{Cl}^{-}$by plants, due to the competition between these nutrients for the absorption site (MENEGHETTE et al., 2017).

For the average fruit mass (Figure 3), it was verified that plants irrigated using water with $\mathrm{ECW}$ of 0.8 and $3.0 \mathrm{dS} \mathrm{m}^{-1}$ did not differ from each other when fertilized with the combinations $\mathrm{C}_{1}, \mathrm{C}_{3}$ and $\mathrm{C}_{5}$. Plants irrigated using water with $\mathrm{ECw}$ of $3.0 \mathrm{dS} \mathrm{m}^{-1}$ and fertilized with the combination $\mathrm{C}_{4}$ (100-125$125 \%$ of N-P-K) reached the highest average fruit mass $(265.6 \mathrm{~g})$, differing significantly from those subjected to the other fertilization combinations. It was also verified that plants irrigated using water with ECw of $3.0 \mathrm{dS} \mathrm{m}^{-1}$ and subjected to the fertilization combination $\mathrm{C}_{4}(100-125-125 \%$ of N-P$\mathrm{K})$ increased their AFM by $38.1 \%$ (73.29 g per fruit) compared to those subjected to $100-100-100 \%$ of $\mathrm{N}$ $\mathrm{P}_{2} \mathrm{O}_{5}-\mathrm{K}_{2} \mathrm{O}\left(\mathrm{C}_{1}\right)$ and irrigated with the same salinity level. On the other hand, plants irrigated with water of $0.8 \mathrm{dS} \mathrm{m}^{-1}$ obtained the highest AFM (223.9 g per fruit) when fertilized with the combination $\mathrm{C}_{2}(100$ $100-125 \%$ of N-P-K).

Plants subjected to the combination $\mathrm{C}_{4}$ possibly maintained the potential for leaf turgor, due to the osmotic adjustment capacity promoted by the synthesis of compatible osmolytes, such as amino acids, stimulated by the increase of $\mathrm{N}$ and $\mathrm{P}$, thus reducing the imbalance between transpiration and water absorption by the plant, favoring osmotic homeostasis (SÁ et al., 2017) and, as a result, there was an increase in the plant's ability to tolerate the effect of salts, which favored their production.

The average number of seeds per fruit (Figure $4 \mathrm{~A})$ of plants irrigated with water of $0.8 \mathrm{dS} \mathrm{m} \mathrm{m}^{-1}$ differed significantly from that of plants cultivated

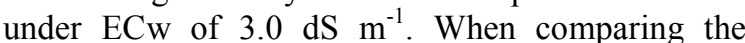
means between treatments, plants under $\mathrm{ECW}$ $0.8 \mathrm{dS} \mathrm{m} \mathrm{m}^{-1}$ showed higher ANSF (38.3 seeds per fruit), while plants irrigated with water of higher salinity level $\left(3.0 \mathrm{dS} \mathrm{m}^{-1}\right)$ produced 29.5 seeds per fruit, that is, a reduction of $23.0 \%$. Reduction in the number of seeds is in line with the number of fruits (Figure 1A). The effect of salinity is manifested mainly in the reduction of the population and development of fruits, with symptoms similar to that of water stress; in general, soil salinity, caused by irrigation with saline water, can result in an increase in the days for harvest and reductions in the number and mass of fruits and seeds, directly influencing the production (OLIVEIRA et al., 2012). 


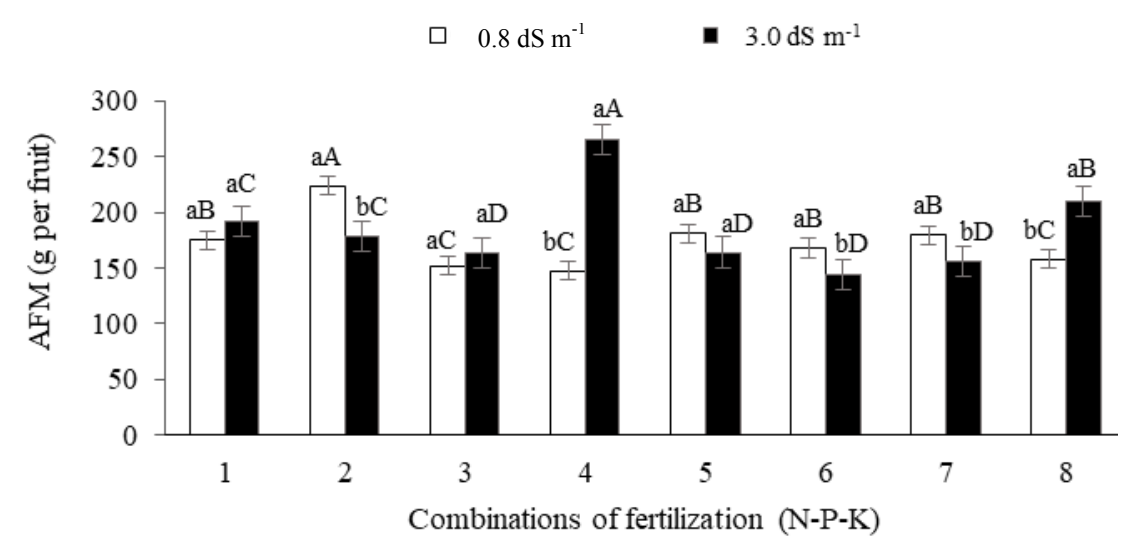

$\mathrm{C}_{1}=100-100-100 ; \mathrm{C}_{2}=100-100-125 ; \mathrm{C}_{3}=100-125-100 ; \mathrm{C}_{4}=100-125-125 ; \mathrm{C}_{5}=125-$ $100-100 ; \mathrm{C}_{6}=125-100-125 ; \mathrm{C}_{7}=125-125-100$ and $\mathrm{C}_{8}=125-125-125 \%$ of the recommended dose of N-P-K; Means with same uppercase letters indicate that there are no significant differences between the combinations of N-P-K fertilization by the Scott-Knott test at 0.05 probability level, and same lowercase letters for the same fertilization combination indicate that there is no significant difference between salinity levels (Tukey test, $\mathrm{p}<0.05$ ).

Figure 3. Average fruit mass - AFM of custard-apple as a function of the interaction between irrigation water salinity $\mathrm{ECW}$ and combinations of fertilization with N-P-K, at harvest.
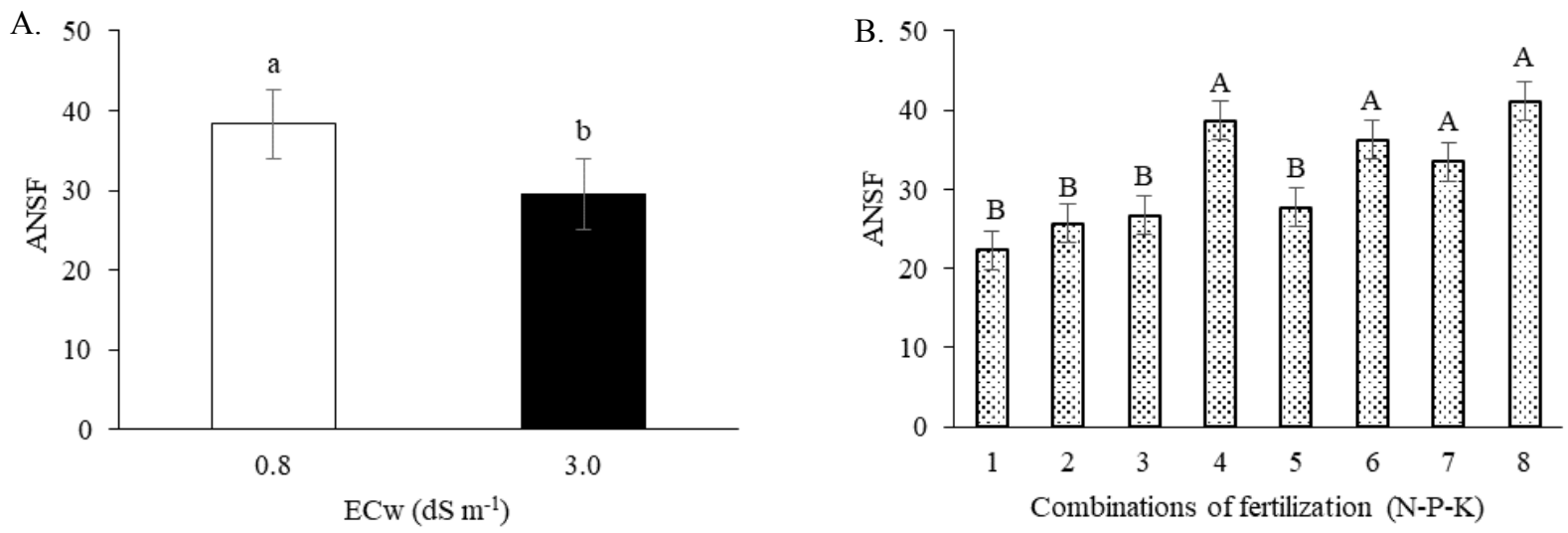

$C_{1}=100-100-100 ; C_{2}=100-100-125 ; C_{3}=100-125-100 ; C_{4}=100-125-125 ; C_{5}=125-100-100 ; C_{6}=125-100-125 ; C_{7}=125$ $-125-100$ and $C_{8}=125-125-125 \%$ of the recommended dose of N-P-K; Means followed by the same letter do not indicate significant differences for salinity of irrigation water (A) and different combinations of fertilization with N-P-K (B), respectively, by the Tukey and Scott-Knott test at 0.05 probability level.

Figure 4. Average number of seeds per fruit - ANSF of custard-apple as a function of irrigation water salinity - ECw (A) and combinations of fertilization with N-P-K (B), at harvest.

The average number of seeds per fruit was significantly influenced by the different fertilization combinations and, according to the means comparison test (Figure 4B), the combinations $\mathrm{C}_{4}$, $\mathrm{C}_{6}, \mathrm{C}_{7}$ and $\mathrm{C}_{8}$ did not differ from each other; however, they led to the highest mean values (38.71, $36.24,33.79$ and 41.11 seeds per fruit, respectively). Nitrogen is an essential element for plants, being a constituent of most biochemical reactions and compounds such as amino acids, proteins and proline, which increase the osmotic adjustment capacity of plants (OLIVEIRA et al., 2014). Phosphorus integrates structural compositions and participates in respiration and photosynthesis, besides being a nutrient involved in energy release processes for metabolic reactions, which favors the absorption and assimilation of $\mathrm{N}$, while potassium favors the formation and translocation of carbohydrates and the efficient use of water by plants (ARAÚJO et al., 2012; SIMÃO et al., 2018). 
Custard-apple is a rustic and demanding plant in terms of nutrients, and in the period of fructification the translocation of photoassimilates becomes preferably directed to the filling of fruits, standing out as a way to ensure the good formation of fruits and seeds, for perpetuation of the species. Thus, the availability of nutrients, especially $\mathrm{N}$, in this stage is extremely important, aiming to optimize photosynthesis and, consequently, the production of photoassimilates (carbohydrates, vitamins, proteins, antioxidants etc.) for their proper drainage by fruits and seeds (SÃO JOSÉ et al., 2014).

The total mass of seeds and the mass of one hundred seeds were negatively affected when custard -apple plants were subjected to irrigation with $\mathrm{ECW}$ of $3.0 \mathrm{dS} \mathrm{m}^{-1}$ (Figure $5 \mathrm{~A}$ and $5 \mathrm{~B}$ ), with reductions of $13.42 \%$ (5.31 g per fruit) and $12.81 \%(2.88 \mathrm{~g})$, respectively, in comparison to plants irrigated with water of $0.8 \mathrm{dS} \mathrm{m}^{-1}$. One of the limitations caused by salt stress is the reduction of photosynthesis, due to the decrease in the availability of $\mathrm{CO}_{2}$ inside the leaves, resulting from the stomatal closure induced by the decrease in the osmotic potential of the soil solution, which directly influences the production of assimilates by the plant, leading to a decrease in the production components (LEMES et al., 2018).
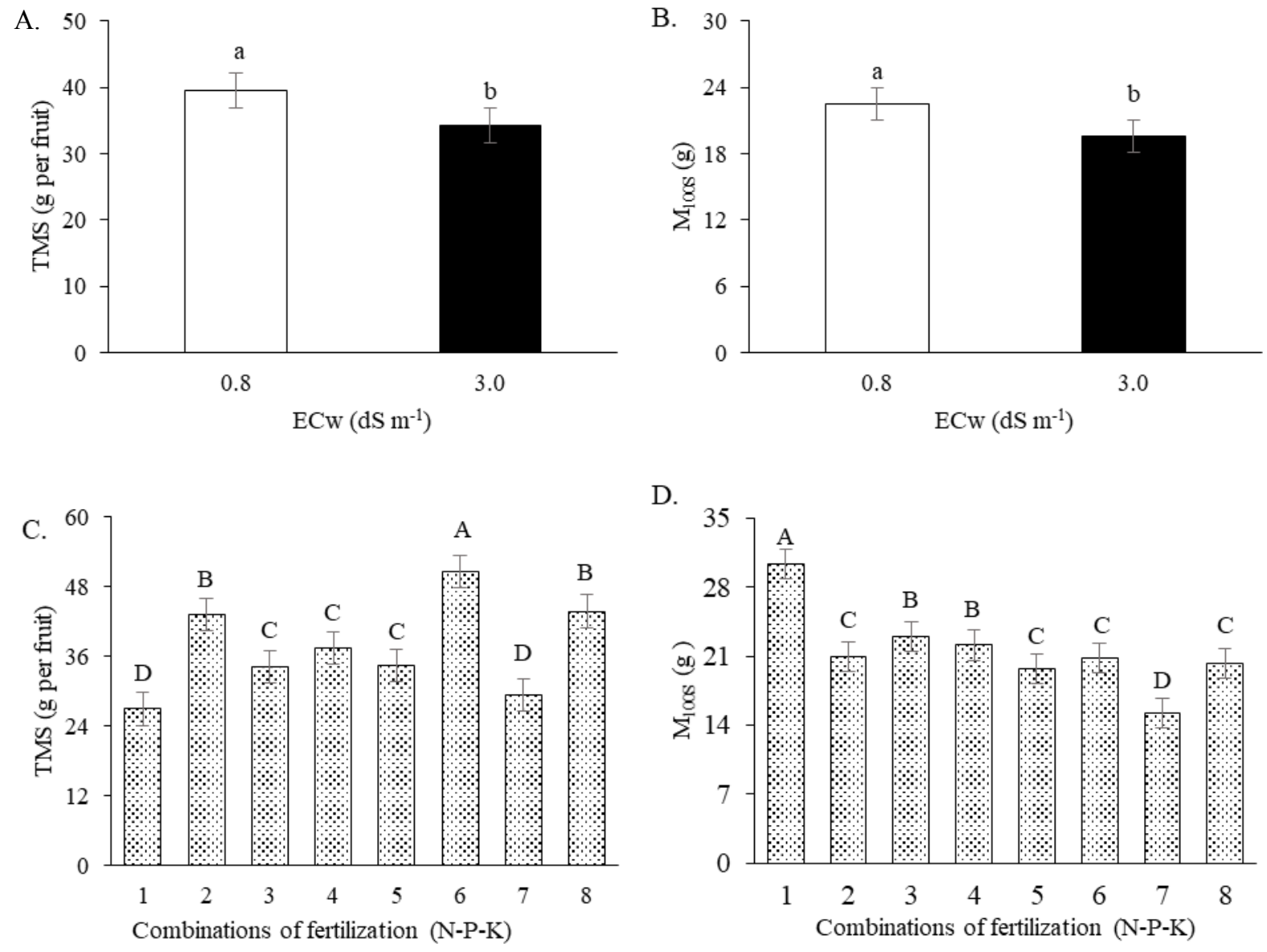

$\mathrm{C}_{1}=100-100-100 ; \mathrm{C}_{2}=100-100-125 ; \mathrm{C}_{3}=100-125-100 ; \mathrm{C}_{4}=100-125-125 ; \mathrm{C}_{5}=125-100-100 ; \mathrm{C}_{6}=125-100-125 ; \mathrm{C}_{7}=125$ $-125-100$ and $C_{8}=125-125-125 \%$ of the recommended dose of N-P-K; Means followed by the same letter do not indicate significant differences for irrigation water salinity (Figures A and B) and different combinations of fertilization with N-P-K (Figures C and D), respectively, by the Tukey and Scott-Knott test, respectively at 0.05 probability level.

Figure 5. Total mass of seeds per fruit - TMS (A) and mass of one hundred seeds - $M_{100 \mathrm{~s}}(\mathrm{~B})$ as a function of irrigation water salinity - ECw and fertilization combinations (C and D), at harvest.

According to Figure 5C, the highest total mass of seeds (50.46 g per fruit) of custard-apple was obtained in plants subjected to the combination of fertilization $\mathrm{C}_{6}$, with an increase corresponding to $87.8 \%$ in comparison to the treatment $C_{1}(100-100$ -
100 N-P-K). Regarding the mass of one hundred seeds (Figure 5D), it is observed that custard-apple plants grown under the combination of fertilization with 100-100-100 of N-P-K obtained the highest value of $\mathrm{M}_{100 \mathrm{~s}}(30.35 \mathrm{~g})$, differing statistically from 
those subjected to the other fertilization combinations. The higher mass of seeds obtained in plants grown under the combination $\mathrm{C}_{6}$ may be related to the increase in nitrogen supply, because this macronutrient is essential to Annonaceae species, affecting the vegetative development of plants, as well as their flowering and production. Nitrogen also plays important role in plant metabolism, participating as a constituent of the chlorophyll molecule, nucleic acids, amino acids and proteins. In addition, seed development and accumulation of storage reserves depend largely on the input of nitrogen $(\mathrm{N})$ into the embryo.

The main form of $\mathrm{N}$ transport is as amino acids that are mainly assimilated in the roots or leaves of plants and that are transformed into sink tissues, such as fruits and seeds (SANDERS et al., 2009; SÃO JOSÉ et al., 2014). It should also be noted that, when plants are under a condition of lower $\mathrm{P}$ concentration, they tend to respond with adaptations that enable the production of viable seeds, which may reduce more the total number of seeds produced than their size (ZUCARELI et al., 2006), supporting the results obtained here, since it can be observed that the number of custard-apple seeds was more affected than the mass of the seeds by the combination of fertilization with $100 \%$ of $\mathrm{P}_{2} \mathrm{O}_{5}$ (Figure 4B and Figure 5D).
For height of custard-apple fruits (Figure 6), it is observed that plants irrigated with water of $0.8 \mathrm{dS} \mathrm{m}^{-1}$ differed significantly from those subjected to $\mathrm{ECw}$ of $3.0 \mathrm{dS} \mathrm{m} \mathrm{m}^{-1}$, except when they were fertilized with the combinations $\mathrm{C}_{3}$. There was also an effect similar to that for AFM (Figure 3), that is, plants irrigated using water of electrical conductivity of $3.0 \mathrm{dS} \mathrm{m}^{-1}$ and fertilized with the combination $\mathrm{C}_{4}(100-125-125 \%$ N-P-K) reached the highest value of fruit height $(89.11 \mathrm{~mm})$, differing significantly from those subjected to the other fertilization combinations. It is also verified that plants irrigated with ECw of $3.0 \mathrm{dS} \mathrm{m}^{-1}$ and under the combination of fertilization $\mathrm{C}_{4}(100-125-125 \%$ of N-P-K) increased their $\mathrm{FH}$ by $13.86 \%$ (12.35 $\mathrm{mm})$ compared to those subjected to $100-100-100 \%$ N-P-K $\left(C_{1}\right)$ and irrigated with the same water salinity level. Generally, plants subjected to high concentrations of specific ions, especially $\mathrm{Na}^{+}$and/or $\mathrm{Cl}^{-}$, may undergo nutritional imbalance; however, when the concentrations of N-P-K in the soil are increased through fertilization, the availability of these nutrients to plants also increases, reducing nutritional imbalance and consequently reducing the negative effects of salinity. Nobre et al. (2013) report that there is evidence of competition in the absorption between nitrate and chloride, so that an increase in nitrate concentration in the root zone may inhibit a greater absorption of chloride by the plant.

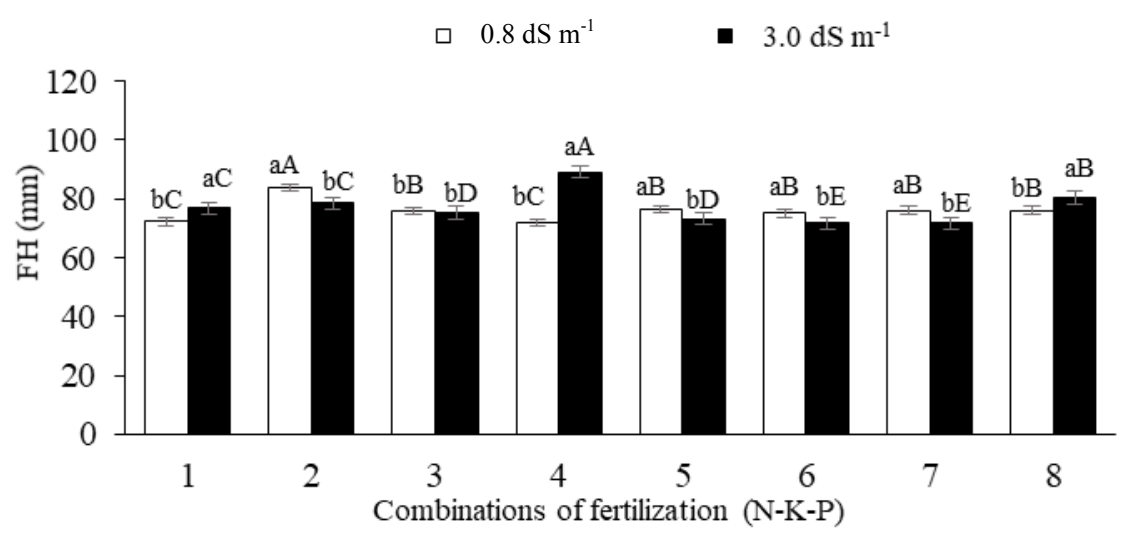

$\mathrm{C}_{1}=100-100-100 ; \mathrm{C}_{2}=100-100-125 ; \mathrm{C}_{3}=100-125-100 ; \mathrm{C}_{4}=100-125-125 ; \mathrm{C}_{5}=125-$ $100-100 ; C_{6}=125-100-125 ; C_{7}=125-125-100$ and $C_{8}=125-125-125 \%$ of the recommended dose of N-P-K; Means with same uppercase letters indicate that there are no significant differences between the combinations of fertilization with N-P-K by the Scott-Knott test at 0.05 probability level, and same lowercase letters for the same fertilization combination indicate that there is no significant difference between salinity levels (Tukey test, $\mathrm{p}<0.05$ ).

Figure 6. Fruit height - FH of custard-apple as a function of the interaction between irrigation water salinity - ECw and combinations of fertilization with NPK, at harvest.

\section{CONCLUSIONS}

High concentrations of salts in the irrigation water reduce the number of fruits, fresh fruit mass, total number of seeds and mass of seeds of custard- apple. Custard-apple plants achieved the best development when grown under the combinations of $125-100-100,125-125-125$ and $100-100-100 \%$ of N-P-K recommendation for the third year of cultivation. Irrigation with water of $3.0 \mathrm{dS} \mathrm{m}^{-1}$ 
associated with the combination of fertilization 100 $125-125 \%$ of N-P-K recommendation increases the average mass and height of custard-apple fruits.

\section{REFERÊNCIAS}

ALVARENGA, C. F. S. et al. Morfofisiologia de aceroleira irrigada com águas salinas sob combinações de doses de nitrogênio e potássio. Revista de Ciências Agrárias, 42: 191-200, 2019.

ANDRADE, F. H. A. et al. Effect of phosphorus application on substrate and use of saline water in sugar-apple seedlings. Pesquisa Agropecuária Tropical, 48: 190-199, 2018.

ARAÚJO, H. S. et al. Doses de potássio em cobertura na cultura da abóbora, Pesquisa Agropecuária Tropical, 42: 469-475, 2012.

AYERS, R. S.; WESTCOT, D. W. A qualidade de água na agricultura. 2. ed. Campina Grande, $\mathrm{PB}$ : UFPB, 1999. 153 p. (FAO. Estudos de Irrigação e Drenagem, 29).

BRASIL. Ministério da Agricultura e Reforma Agrária. Regras para análise de sementes. 1. ed. Brasília, DF: MAPA, 2009. 399 p.

CAVALCANTE, L. F. et al. Nutritional status of the sugar apple under organic fertilizing of the soil. Revista Ciência Agronômica, 43: 579-588, 2012.

CLAEYS, H. et al. What is stress? Dose-response effects in commonly used in vitro stress assays. Plant Physiology, 165: 519-527, 2014.

DIAS, A. S. et al. Gas exchanges and photochemical efficiency of West Indian cherry cultivated with saline water and potassium fertilization. Revista Brasileira de Engenharia Agrícola e Ambiental, 22: 628-633, 2018.

DIAS, A. S. et al. Gas exchanges, quantum yield and photosynthetic pigments of West Indian cherry under salt stress and potassium fertilization. Revista Caatinga, 32: 429-439, 2019.

FERNANDES, E. A. et al. Cell damage, gas exchange, and growth of Annona squamosa L. under saline water irrigation and potassium fertilization. Semina: Ciências Agrárias, 42: 999-1018, 2021.

FERREIRA, D. F. SISVAR: A computer analysis system to fixed effects split plot type designs. Revista Brasileira de Biometria, 37: 529-535, 2019.
FERREIRA, F. N. Águas salinas e combinações de adubação com NPK no cultivo de pinheira no segundo ciclo. 2020. 82 p. (Mestrado em Engenharia Agrícola: Área de concentração em Irrigação e Drenagem). Universidade Federal de Campina Grande, Campina Grande. 2020.

FERREIRA, F. N. et al. Photosynthetic efficiency and production of Annona squamosa L. under salt stress and fertilization with NPK. Revista Brasileira de Engenharia Agrícola e Ambiental, 25: 446-452, 2021 .

FLOWERS, T. J.; MUNNS, R.; COLMER, T. D. Sodium chloride toxicity and the cellular basis of salt tolerance in halophytes. Annals of Botany, 115: 419 $-431,2014$.

LEMES, E. S. et al. Salinidade na cultura do arroz irrigado: características agronómicas e qualidade de sementes. Revista de Ciências Agrárias, 4: 131$140,2018$.

LIMA, G. S. de et al. Eficiência fotoquímica, partição de fotoassimilados e produção do algodoeiro sob estresse salino e adubação nitrogenada. Revista de Ciências Agrárias, 42:211-220, 2019.

MEDEIROS, J. F. Qualidade da água de irrigação e evolução da salinidade nas propriedades assistidas pelo "GAT" nos Estados do RN, PB e CE. 1992. 173 p. Dissertação (Mestrado em Engenharia Agrícola: Área de concentração em Irrigação e Drenagem) - Universidade Federal da Paraíba, Campina Grande, 1992.

MENEGHETTE, H. H. A. et al. Doses de fósforo e potássio em plantas de amendoim na presença e ausência de adubação foliar. Revista Brasileira de Engenharia de Biossistemas, 11: 125-134, 2017.

NOBRE, R. G. et al. Emergência, crescimento e produção da mamoneira sob estresse salino e adubação nitrogenada. Revista Ciência Agronômica, 44: 76-85, 2013.

OLIVEIRA, F. A. et al. Produção do algodoeiro em função da salinidade e tratamento de sementes com regulador de crescimento. Revista Ciência Agronômica, 43: 279-287, 2012.

OLIVEIRA, F. A. et al. Interação entre salinidade da água de irrigação e adubação nitrogenada na cultura da berinjela. Revista Brasileira de Engenharia Agrícola e Ambiental, 18: 480-486, 2014.

OUHADDACH, M. et al. Morpho-physiological and biochemical responses to salt stress in wheat 
(Triticum aestivum L.) at the heading stage. Journal of Materials and Environmental Sciences, 9: 1899 $-1907,2018$.

PRAZERES, S. S. et al. Crescimento e trocas gasosas de plantas de feijão-Caupi sob irrigação salina e doses de potássio. Revista Agroambiente On-line, 9: 111-118, 2015.

SÁ, F. V. S. et al. Water relations and gas exchanges of West Indian cherry under salt stress and nitrogen and phosphorus doses. Journal of Agricultural Science, 9: 168-177, 2017.

SÁ, F. V. S. et al. The right combination of NPK fertilization may mitigate salt stress in custard apple (Annona squamosa L.). Acta Physiologiae Plantarum, 43: 1-12, 2021.

SANDERS, A. et al. AAP1 regulates import of amino acids into developing Arabidopsis embryos. The Plant Journal, 59: 540-552, 2009.

SÃO JOSÉ, A. R. et al. Cultivo da graviola. In: SEMANA INTERNACIONAL DE FRUTICULTURA E AGROINDÚSTRIA, 7. 2000, Fortaleza. Anais... Fortaleza: FRUTAL, 2000. 36 p.

SÃO JOSÉ, A. R. et al. Marcha de absorção de nutrientes em anonáceas. Revista Brasileira de Fruticultura, 36: 176-183, 2014.

SILVA, A. Q.; SILVA, H. Nutrição e adubação de anonáceas. In: SÃO JOSÉ, A.R.; SOUZA, I. V. B.; MORAIS, O. M.; REBOUÇAS, T. N. H. (Eds.) Anonáceas, produção e mercado (pinha, graviola, atemóia e cherimólia). Vitória da Conquista, BA: UESB - DFZ, 1997. v. 1, cap. 9, p. 118-137.

SILVA, A. R. et al. Frequency of irrigation with saline water in sugar-apple seedlings produced on substrate with polymer. Revista Brasileira de Engenharia Agrícola e Ambiental, 22: 825-830, 2018.

SIMÃO, E. P. et al. Resposta do milho safrinha à adubação em duas épocas de semeadura. Revista Brasileira de Milho e Sorgo, 17: 76-90, 2018.

SOUZA, J. A. et al. Ecofisiologia e rendimento forrageiro do capim elefante roxo em função de adubação nitrogenada. Archivos de Zootecnia, 68: 464-470, 2019.

TEIXEIRA, P. C. et al. Manual de métodos de análise de solo. 3. ed. Brasília, DF: Embrapa Solos, 2017. 573 p.

VELOSO, L. L. S. A. et al. Effects of saline water and exogenous application of hydrogen peroxide $\left(\mathrm{H}_{2} \mathrm{O}_{2}\right)$ on soursop (Annona muricata L.) at vegetative stage. Australian Journal Crop Science, 13: 472-479, 2019.

ZUCARELI, C. et al. Adubação fosfatada, componentes de produção, produtividade e qualidade fisiológica em sementes de feijão. Revista Brasileira de Sementes, 28: 9-15, 2006.

This work is licensed under a Creative Commons Attribution-CC-BY https://creativecommons.org/licenses/by/4.0/ 